\title{
Behaviour of factors II, VII, IX and X in bleeding complications during long-term treatment with Coumarin
}

Citation for published version (APA):

Loeliger, E. A., Hensen, A., Mattern, M. J., \& Hemker, H. C. (1964). Behaviour of factors II, VII, IX and X in bleeding complications during long-term treatment with Coumarin. Thrombosis et diathesis haemorrhagica, 10(3/4), 278-281. https://doi.org/10.1055/S-0038-1654783

Document status and date:

Published: 01/01/1964

DOI:

10.1055/S-0038-1654783

Document Version:

Publisher's PDF, also known as Version of record

Please check the document version of this publication:

- A submitted manuscript is the version of the article upon submission and before peer-review. There can be important differences between the submitted version and the official published version of record.

People interested in the research are advised to contact the author for the final version of the publication, or visit the DOI to the publisher's website.

- The final author version and the galley proof are versions of the publication after peer review.

- The final published version features the final layout of the paper including the volume, issue and page numbers.

Link to publication

\footnotetext{
General rights rights.

- You may freely distribute the URL identifying the publication in the public portal. please follow below link for the End User Agreement:

www.umlib.nl/taverne-license

Take down policy

If you believe that this document breaches copyright please contact us at:

repository@maastrichtuniversity.nl

providing details and we will investigate your claim.
}

Copyright and moral rights for the publications made accessible in the public portal are retained by the authors and/or other copyright owners and it is a condition of accessing publications that users recognise and abide by the legal requirements associated with these

- Users may download and print one copy of any publication from the public portal for the purpose of private study or research.

- You may not further distribute the material or use it for any profit-making activity or commercial gain

If the publication is distributed under the terms of Article 25fa of the Dutch Copyright Act, indicated by the "Taverne" license above, 


\section{THROMBOSIS ET DIATHESIS HAEMORRHAGICA}

EDITORES: K. M. BRINKHOUS, CHAPEL HILL; F. BUCHNER, FREIBURG/BREISGAU; E. DEUTSCH, WIEN; J. E. JORPES, STOCKHOLM; F. KOLLER, BASEL; J. ROSKAM, LIËGE; J.-P. SOULIER, PARIS; I. S. WRIGHT, NEW YORK

Behaviour of Factors II, VII, IX and X in Bleeding Complications During Long-Term Treatment with Coumarin

From the Haematology Section of the Department of Internal Medicine (Head: Prof. J. Mulder, M.D.), University Hospital, and the Thrombosis Service (Head: E. A. Loeliger, M.D.), Leyden, The Netherlands

E. A. Loeliger, A. Hensen, Mieke J. Mattern and $\mathrm{H}$. C. $\mathrm{H}$ e $\mathrm{m} \mathrm{ke} \mathrm{r}$

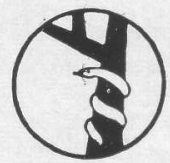


In a recent publication we reported on the behaviour of Factors II, VII, IX, and $\mathrm{X}$ during adequate long-term treatment with various coumarin derivatives (3). The activity of the four factors appeared to be lowered almost equally, to a mean activity of about $20 \%$ of normal. Most surprisingly, however, and at that time inexplicably, the mean thrombotest activity was not lowered accordingly, displaying instead a stronger depression, down to about $13 \%$ of normal, on the average.

Since then we have collected data concerning the behaviour of Factors II, VII, IX, and X in 20 cases of bleeding complications during long-term treatment with the coumarin derivative phenprocoumon (Marcoumar "Roche"). The results of this study will be given here.

\section{Material and Methods}

Glassware, thromboplastin, phospholipid, buffer, samples of normal and patient's plasma, normal $\mathrm{BaSO}_{4}$-adsorbed plasma, artificially Factor II- and X-deficient as well as congenitally Factor VII- and IX-deficient substrate plasmas were prepared as previously described (3).

Factors II and $\mathrm{X}$ were determined only with the artificially factor-deficient substrate plasma, Factors VII and IX only with the congenitally factor-deficient substrate plasma.

The coagulation factor assay system and the calculation of the coagulation factor activity have also been published earlier (3).

\section{Patients and Normal Controls}

During a period of several months, all bleeding complications in our material of about 1300 patients under the care of the thrombosis service were recorded. Those occurring in patients treated for more than 3 months and displaying no evidence of sudden change in coagulability prior to bleeding were chosen for the coagulation factor study. The normal controls were taken at random from personnel of the University Hospital. Samples from both patients and normals were not taken after fasting.

Thrombos. Diathes. haemorrh. 


\section{Results}

Most of the 20 patients, at the time of bleeding, showed unusually strong hypocoagulability, as reflected by the mean thrombotest value of about $5 \%$ of normal. The individual as well as the mean values are given in Table 1.

Statistical analysis* of the figures revealed no statistically significant difference between the mean values of the 4 factors $(p=0.4)$. Individually considered, however, the coefficient of variation of the chance fluctuation appeared to

T a b le 1: Activity of coagulation factors II, VII, IX, and $\mathrm{X}$ in coumarin-treated patients suffering from bleeding complications. Patients nr. 1, 3, 4, 6-11, 13, 15, and 19 displayed macrohaematuria, patient nr. 2 cerebral haemorrhage, patient nr. 5 a traumatic spleen rupture, patient nr. 12 epistaxis, and patients nr. 14, 16-18, and 20 melaena

\begin{tabular}{|c|c|c|c|c|}
\hline \multirow{2}{*}{ patient nr. } & \multicolumn{4}{|c|}{$\begin{array}{c}\text { coagulation factor activity } \\
\text { (per centage) }\end{array}$} \\
\hline & II & VII & IX & $\mathrm{X}$ \\
\hline 1. & 7.5 & 9.0 & 10.0 & 10.0 \\
\hline 2. & 18.0 & 18.0 & 22.0 & 17.0 \\
\hline 3. & 3.5 & 8.0 & 5.0 & 9.0 \\
\hline 4. & 12.0 & 14.0 & 14.0 & 7.0 \\
\hline 5. & 19.0 & 16.0 & 20.0 & 10.0 \\
\hline 6. & 5.5 & 6.0 & 8.0 & 9.5 \\
\hline 7. & 10.0 & 10.0 & 10.0 & 9.0 \\
\hline 8. & 9.5 & 8.5 & 16.0 & 13.0 \\
\hline 9. & 7.5 & 4.0 & 8.5 & 9.0 \\
\hline 10. & 8.5 & 6.0 & 4.0 & 8.0 \\
\hline 11. & 4.0 & 6.5 & 4.0 & 12.0 \\
\hline 12. & 11.0 & 24.0 & 8.0 & 18.0 \\
\hline 13. & 19.0 & 24.5 & 24.0 & 13.5 \\
\hline 14. & 23.0 & 19.0 & 13.0 & 14.0 \\
\hline 15. & 4.0 & 4.5 & 8.0 & 5.0 \\
\hline 16. & 5.5 & 4.5 & 4.0 & 4.0 \\
\hline 17. & 26.0 & 16.0 & 45.0 & 25.0 \\
\hline 18. & 17.0 & 23.0 & 26.0 & 11.5 \\
\hline 19. & 20.0 & 27.0 & 18.0 & 23.0 \\
\hline 20. & 18.5 & 27.0 & 19.0 & 13.0 \\
\hline N 20 & $12.45 \%$ & $13.8 \%$ & $14.3 \%$ & $12.0 \%$ \\
\hline
\end{tabular}

* We are indebted to Dr. E. F. Drion, Head of the Statistics Department T. N. O., The Hague, for his invaluable help with the statistical analysis. 
be $35 \%(30.5 \%$ when the values of patient $\mathrm{nr} .17$ were omitted), which is considerably higher than the $22 \%$ found in normal individuals or in adequately treated patients (3).

\section{Discussion}

It is our experience that in the beginning of coumarin therapy, bleeding complications occur as the result of a combined Factor VII- and IX-deficiency, caused by the relatively rapid disappearance of these 2 coagulation factors when their synthesis is blocked by the initial loading dose of coumarin. Bleeding complications during long-term treatment, on the other hand, appear not to be due to a selective coagulation factor deficiency, as can be concluded from the present study. Factors II, VII, IX, and X behave as under so-called adequate therapeutic conditions, except that the average intensity of the decrease is stronger and the coefficient of variation of the chance fluctuation is higher. Differences in activity between the 4 factors are not statistically significant; the higher chance fluctuation, most likely, is due to the fact that bleeding often interrupts the steady state situation.

Interestingly enough, thrombotest again indicates a significantly. lower activity than that found for the coagulation factors when determined separately, the average values being 5\% (read from the producer's standard curve) and $13 \%$, respectively. The size of the disparity appears to be higher than in adequately treated patients (13\% thrombotest as against $20 \%$ factor activity), which can be explained by the inaccuracy of thrombotest readings for values lower than $5 \%$ of normal. The main difference, however, in both instances is due to a circulating anticoagulant involved in coumarin therapy, as recently demonstrated in our laboratory $(1,2)$.

\section{Summary}

In 20 patients suffering from bleeding complications during long-term treatment with phenprocoumon, the depression of the activity of Factors II, VII, IX and X, on the average, was found to be stronger than in so-called adequately treated patients, whereas no statistically significant differences could be demonstrated between the average activity of the 4 factors. The individual variations between the 4 factors were higher than those found in normal individuals and adequately treated patients.

Thrombotest activity appeared to be considerably lower than the average factor activity. This discrepancy is mainly caused by the action of the recently discovered circulating anticoagulant occurring in coumarin-treated or vitamin K-deficient patients. 


\section{Résumé}

Dans 20 cas de complication hémorragique pendant le traitement prolongé à la phenprocoumon, la dépression de l'activité des facteurs II, VII, IX et X était plus accentuée, en moyenne, que pendant le traitement adéquat, tandis qu'entre les moyennes de l'activité des 4 facteurs il n'y avait pas de différences statistiquement significatives. Les variations individuelles des 4 facteurs étaient un peu plus accentuées que celles observées chez des individus normaux et chez des malades traités de façon adéquate.

L'activité "thrombotest" était considérablement plus basse que l'activité moyenne des 4 facteurs. Cette différence est essentiellement due à un anticoagulant circulant apparaissant pendant le traitement à la coumarine ou en cas d'avitaminose $\mathrm{K}$.

\section{Zusammenfassung}

In 20 Fällen von Blutungskomplikation während Langzeitbehandlung mit Phenprocoumon war die durchschnittliche Senkung der Faktor II-, VII-, IXund X-Aktivität stärker als bei adäquat behandelten Patienten, jedoch ohne statistisch signifikanten Unterschied zwischen den 4 Faktoren. Die individuellen Unterschiede zwischen den 4 Faktoren waren etwas größer als die bei Normalen und adäquat Behandelten gefundenen.

Die Thrombotest-Aktivität war durchschnittlich bedeutend niedriger als die Faktoren-Aktivität. Diese Diskrepanz beruht hauptsächlich auf der Wirkung eines vor kurzem entdeckten, während Coumarinbehandlung und bei Vitamin-KMangel auftretenden zirkulierenden Antikoagulans.

\section{References}

(1) Hemker, H. C., J. J. Veltkamp, A. Hensen and E. A. Loeliger: Preprothrombin (complex?), a circulating anticoagulant in coumarin-treated and vitamin K-deficient patients. Proc. Gleneagles Conf., Int. Comm. for the Nomenclature of Blood Clotting Factors, 1963. Thrombos. Diathes. haemorrh. (Stuttg.) to be published in 1964.

(2) Hemker, H. C., J. J. Veltkamp, A. Mensen and E. A. Loeliger: Nature of prothrombin biosynthesis. Nature 200: 589 (1963).

(3) Loeliger, E. A., B. van der Esch, M. J. Mattern and A. S. A. den Bra$\mathrm{b}$ a nder: Behaviour of factors II, VII, IX, and $\mathrm{X}$ during long-term treatment with coumarin. Thrombos. Diathes. haemorrh. (Stuttg.) 9: 74 (1963).

Received for publication 20.9.1963

Der Verlag behält sich alle Rechte, besonders die des Nachdruckes, der Vervielfältigung und der Ubersetzung, vor. 